\title{
Vocational High School's Superior Products Mapping to Support Bandung as a Creative Industry City and National Product Development
}

\author{
Syamsul Hadi Senen, Bambang Widjajanta Dian H. Utama, Masharyono \\ Universitas Pendidikan Indonesia \\ syamsulhadisenen@upi.edu
}

\begin{abstract}
The problem of this research is how to get the mapping of vocational high schools by using multidimensional scaling based on the superior products produced. The purpose of the mapping is to categorize vocational high schools in Bandung based on the superior products produced in which the categorization result can be a reference for Bandung's government to choose superior products from vocational high schools to be developed into national product. The method used was descriptive analytics. The results are the categorization of vocational high school with the same superior products' characteristics based on its fields of expertise.
\end{abstract}

Keywords-creative industry; mapping; national product; superior products

\section{INTRODUCTION}

The government through the Ministry of National Education has three pillars of strategic policy in education, namely equal distribution and extension for educational access, improvement of quality and education relevance, and reinforcement of governance and public image. The first pillar is that education should be able to be enjoyed by the entire components of the nation, whether it is for the remote and city people or for the poor and rich people. The second pillar is that the globalization which influences all of the life aspects demands our human resources to have a high competitive ability, hence high quality education is needed to compete with other countries. The third pillar is that education must be convincing, so the society knows that only through education our dreams to be an advanced and prosperous country can be achieved.

As the follow-up of this policy, especially in secondary education, the National Education Department has an empowerment program for vocational high school (SMK) by increasing the number of SMK, improving the quality of SMK, and improving the image of SMK in the society. The program of the National Education Department in 2015 is to make the proportion of vocational high school and high school 70:30, whether it is for the number of schools or for the number of students. This step was done to strengthen the position of labor in the secondary level in terms of the number and its quality in order to face the endorsement of free trade. In addition, the large number of SMK is expected to increase the economic growth in the regions.
The increasing number of people who are interested in SMK brings new problems, the number of SMK graduates is not supported by sufficient number of employment hence a classic problem occurs; unemployment. Based on the data from BPS, the number of unemployment in Indonesia on August 2011 is 7.7 million people or $6,56 \%$. This number had declined from 8,12 million people or 6.8 percent in February 2011. Indonesia open unemployment in August 2011 is dominated by vocational high school graduates. Compared to the condition in February 2011, the highest open unemployment rate for high school graduates (high school) and vocational high school (SMK) is $10,66 \%$ and $10,43 \%$. While for the unemployment of primary school graduates (primary) and under, the number increased 3,56\% of the percentage on February 2011 at 3,37\%. Then, unemployment of junior high school graduates reached $8,37 \%$ or increased from February $20117,83 \%$. Then, unemployment of diploma graduates I / II / III reached 7,16 \% or decreased from February 2011 of 11,59\%. The last, unemployment of university graduates decreased to $8,02 \%$ from 9,95\% in February 2011. On August 2011, the number of workers in Indonesia is dominated by primary school graduates or under on the total of 54,2 million or $49,4 \%$. As for workers with diploma degree is only about 3.2 million people or $2,89 \%$ and workers with bachelor degree is only around 5.6 million people or $5,15 \%$. Based on the data, it can be seen that the main issue is providing employment opportunities. Vocational high school graduates are not only getting an education that link and match with the fieldwork, but also must be able to provide jobs [1].

Bandung as the city with the second highest number of SMK after Bogor city and regency on West Java [2] also has high quality products produced either by the public or private vocational high school. There are a lot of high quality products created by SMK in Bandung that will give a big contribution to improve the image of Bandung as a creative industry city. Although the superior products have been already produced by many vocational high school students in Bandung, currently there is still no information regarding the mapping of those superior products that have the potential to be national products. 


\section{LITERATURE STUDY}

\section{A. Product}

The core of marketing hotchpotch is the product offered. A product is designed to meet the needs of market goals predetermined and usually treated as a starting point in making a marketing hotchpotch. A manager cannot determine the price, a strategy of promotion, or a distribution channel strategy before the company determines the sale. The product is defined as anything offered at the market to be considered, owned, used to satisfy the desire or need, including the physical object, services, places, organizations and ideas [3].

\section{B. Product Attributes}

Attribute of the products is very influential towards the reaction of customers to a product. The product's attribute is one of the factors that determines the value of a product designed by the company. In offering a product to consumers, the companies should determine what benefits that will be given by the product. Then, these benefits are communicated and fulfilled by the products' attribute which are formed into product quality, product features which determine the rate of customer satisfaction. Categorize the attribute of product into three important elements, namely product quality, product features, and design product [4].

\section{Product Quality Dimensions}

A part of the product policy is regarding quality products. The quality of a product in a form of both goods or services must be determined by its dimensions defines eight dimensions used to analyze a product [5], namely:
1) Performance
2) Features
3) Conformance
4) Reliability
5) Durability
6) Service ability
7) Aesthetics
8) Perceived Quality

\section{Image}

When talking about image, there will be an imagery of an assessment of something, namely someone, a good or service, an institution or agencies. The image of the picture depends on the experience or information commonly heard, if the information heard is good, there will be a positive view towards something or someone, goods and services and the information or institutions. Otherwise, if the experience or information received or heard is bad, a bad picture will appear. Imagery is the public perception of the company or its products of goods and services. An image is an evaluation inside someone based on the experience towards stimuli that has been already processed, organized in someone's mind. Basically, this definition of image is intangible, but the image of assessment can be perceived from a good assessment as a kind of the respect or normal mass, from the public around or society in general [6].

\section{E. City Image}

The image of the city itself can be defined as a mental picture of a city in accordance with the society views [7]. City image describes an equation of combined number or a unit of information connected with the place [8] [9].

\section{RESEACH METHODOLOGHY}

Based on the variables investigated, this research is a descriptive research. The development method used in this research was a cross sectional method. The subject of this research is 15 public schools and 20 private schools in Bandung. The data were collected by the means of questionnaires. The data were analyzed through descriptive analysis technique.

\section{DISCUSSIONS}

If it was seen from the school categorization based on the results of the questionnaire, there are SMK economic, SMK engineering, SMK pharmaceutical, SMK informatics, SMK tourism, SMK graphic, SMK musical, and SMK culinary. Whereas, if it was categorized based on the superior products produced by the schools, the groups are as follows:

\section{TABLE I. SUPERIOR PRODUCTS OF SMKN}

\begin{tabular}{|c|c|c|}
\hline No & Public School & Superior Product \\
\hline 1 & SMKN 1 Bandung & $x^{2}=$ \\
\hline 2 & SMKN 2 Bandung & $\begin{array}{l}\text { Tad Gate } \\
\text { Moving stage } \\
\text { Simulation aids earthquake } \\
\text { Biopori }\end{array}$ \\
\hline 3 & SMKN 3 Bandung & $\begin{array}{l}\text { Bina usaha esemka tours and travel } \\
\text { Bisa usaha esemka retail and } \\
\text { wholesale }\end{array}$ \\
\hline 4 & SMKN 4 Bandung & Laptop Advance \\
\hline 5 & SMKN 5 Bandung & $\begin{array}{l}\text { Design } \\
\text { Yoghurt }\end{array}$ \\
\hline 6 & SMKN 6 Bandung & $\begin{array}{l}\text { Life engine stand } \\
\text { Cutaway engine stan } \\
\text { Car trainer } \\
\text { Simulator } \\
\text { Inverter DC to AC } \\
\text { Kusen (pintu dan jendela) } \\
\text { Mebeler } \\
\text { Maket }\end{array}$ \\
\hline 7 & SMKN 7 Bandung & $\begin{array}{l}\text { Honey soap } \\
\text { Beverages (VCO, The Rosela) } \\
\text { Hand sanitizer } \\
\text { Aromatherapy oil }\end{array}$ \\
\hline $\begin{array}{l}8 \\
9\end{array}$ & $\begin{array}{l}\text { SMKN } 8 \text { Bandung } \\
\text { SMKN } 9 \text { Bandung }\end{array}$ & Biggy car \\
\hline 10 & SMKN 10 Bandung & - \\
\hline 11 & SMKN 11 Bandung & - \\
\hline 12 & SMKN 12 Bandung & Assemble Trainer PLC \\
\hline 13 & SMKN 13 Bandung & - \\
\hline 14 & SMKN 14 Bandung & $\begin{array}{l}\text { Bed cover } \\
\text { Batik } \\
\text { Jewelry }\end{array}$ \\
\hline 15 & SMKN 15 Bandung & - \\
\hline
\end{tabular}

a. Source: Data 2016 
While the portrayal of superior products of private vocational high schools is as follows:

TABLE II. SUPERIOR PRODUCTS OF PRIVATE SMK

\begin{tabular}{|c|c|c|}
\hline No & Private School & Superior Product \\
\hline 1 & SMK Profita Bandung & $\begin{array}{l}\text { Profita Wininet } \\
\text { Ritel } \\
\text { Services financial report }\end{array}$ \\
\hline 2 & SMK Ganesha & $\begin{array}{l}\text { Gant (An instrument for } \\
\text { measuring carpentry) }\end{array}$ \\
\hline 3 & SMK Prakarya Internasional 1 & $\begin{array}{l}\text { Siku blok } \\
\text { A stove parapin } \\
\text { Ragum universal } \\
\text { Klem sejajar } \\
\text { Tracker } \\
\text { Tang combination } \\
\text { water pump } \\
\text { Contractor } \\
\text { Spraying water }\end{array}$ \\
\hline 4 & SMK Pasundan 1 & Supermarket \\
\hline 5 & SMK Muhammadiyah 1 & - \\
\hline 6 & SMK Bina Warga & $\begin{array}{l}\text { Kripik nu geulis } \\
\text { lanterns nu geulis } \\
\text { Bread nu geulis }\end{array}$ \\
\hline 7 & SMK Taman Siswa & - \\
\hline 8 & SMK Ma'arif & - \\
\hline 9 & SMK BPI & - \\
\hline 10 & SMK Pajajaran 2 & - \\
\hline 11 & SMK Informatika & - \\
\hline 12 & SMK MVP International & Mask \\
\hline 13 & SMK Pasundan 3 & $\begin{array}{l}\text { Video Shoot } \\
\text { Photography }\end{array}$ \\
\hline 14 & SMK RA Kartini & $\begin{array}{l}\text { Veil } \\
\text { Cookies } \\
\text { Catering }\end{array}$ \\
\hline 15 & SMK Kiansantang & - \\
\hline 16 & SMK Farmasi BPK Penabur & Floor cleaner \\
\hline 17 & SMK Angkasa Husein S & Motor \\
\hline 18 & SMK Prima Grafika & - \\
\hline 19 & SMK Daarut Tauhid & $\begin{array}{l}\text { E-zakat application } \\
\text { Automatic Bell } \\
\text { T-shirt Design }\end{array}$ \\
\hline 20 & SMK Farmasi Bumi Siliwangi & - \\
\hline
\end{tabular}

This subsector development planning is a part of the advanced planning of the Indonesia economy development planning by looking in more details to each sub sector of creative industry. The vocational high school products which might be able to develop in the future are: tad gate (a machine scarlet goods), moving stage (a machine the moving stage), earthquake simulation aids, Biopori (a hole maker machine in the ground), laptop, life engine Stan, cutaway engine Stan, car trainer, simulator, inverter $\mathrm{DC}$ to $\mathrm{AC}$, the sills (door and windows), mebeler, market, honey soap, beverages (VCO, the Rosela), hand sanitizer, the aromatherapy oil, biggy car, bed cover, batik fabrics, jewelry, retail, financial reports services, and motor.

\section{CONCLUSION}

The existing vocational high schools in Bandung can be classified into SMK economics, SMK engineering, SMK pharmaceutical, SMK informatics, SMK tourism, SMK graphics, SMK musical, and SMK culinary.

SMK has an important role in building Bandung as a creative city with its product produced and it is known now Bandung has been one of the cities in Indonesia which is being proposed to be a creative city to UNIESCO.

\section{REFERENCES}

[1] www.datapokok.ditpsmk.net

[2] www.datapokok.ditpsmk.net

[3] Armstrong G, Adam S, Denize S, Kotler P. Principles of marketing. Pearson Australia; 2014 Oct 1.

[4] Kotler, Phillip dan Armstrong, Gary, Principles of Marketing, Englewood Cliff, New Jersey: Prentice Hall. 2004.

[5] Garvin A., David.," Manufacturing Strategic Planning", diterjemahkan oleh Hamel, Cetakan 3, Jakarta: PT. Gramedia Pustaka Utama.1997.

[6] Kotler, Philip, Marketing Management, Jakarta, Prenhallindo. 2007

[7] Turner T. City as landscape: a post post-modern view of design and planning. Taylor \& Francis; 2014 Apr 4.

[8] Lynch K. The image of the city. Kevin Lynch Papers, MC 208, Box 1, General Statements (2 of 2), MIT Institute Archives and Special Collections, Cambridge, MA, 19541959. 1954.

[9] Carmona M. Public places, urban spaces: the dimensions of urban design. Routledge; 2010. 